\title{
REDEVELOPMENT SITE OF ABDALI : WILL IT IMPROVE THE QUALITY OF LIFE AT AMMAN, JORDAN?
}

Samer Abu-Ghazalah, B. Arch., M. Phil. (UK), Ph.D. (UK), Hon. Dip. Arch. (U.K)

Associate Professor, Department of Architecture University of Jordan

Address P.O. Box 926966 AMMAN 11190 JORDAN

Fax No.++96265676213_Email: sabugh@yahoo.com

(Received April 1, 2006 Accepted April 29, 2006)

\begin{abstract}
Although the interest in "quality of life" studies appeared at the middle of the $20^{\text {th }}$ century (around 1950) as part of the economic, social, and environmental studies, developing Middle Eastern countries did not start to examine it in detail until the beginning of the $21^{\text {st }}$ century. The need to measure the quality of life of a city or a district is considered a vital part of the growth and urbanization process that is happening at an incredible rate without the ability to control or analyze it.

Quality of life means measurement of people's satisfaction and the quality of the environment in which they live. Jordan recently started an economic reform process that involves improving the climate for foreign investment to improve the economy. The redevelopment site of Abdali, near the city center, is one example of foreign investment projects that will be examined in this paper. The site was originally being used for administrative buildings for the army. The site area is around 350,000 square meters, with a developed area of over one million square meters. The project will cost over US\$ one billion. The infrastructure for this project is nearly completed and the construction will start at the beginning of the year 2006 and will take several years. In this study a measure of expected future quality of life after the redevelopment project takes place will be examined, and a number of conclusions have been reached at end.
\end{abstract}

KEYWORDS: Quality of life, domains, concept mapping technique, city profile,

\section{INTRDUCTION}

\subsection{Amman City}

Amman is a modern city, although its history dates back to 9000 years ago. In 1878, a group of Circassians settled in Amman from the Turkish Empire from which grew the first settlement at the beginning of the $20^{\text {th }}$ century. In 1922 Amman became the capital of Jordan. In 1925 two small settlements existed near each other which continued to 
grow until 1939, when the population reached 20 thousand inhabitants. [1]. The growth of Amman was influenced greatly by the political situations of the region. The first urban fabric existed between 1920 and 1948, where the growth of Amman was relatively slow and the local materials of masonry and sand were used. Amman's total area was estimated to be only 5 square kilometers. Between 1948 and 1956 a huge number of refugees coming from Palestine settled in Amman. The total population increased to about 225 thousand inhabitants. Between 1956 and 1967 the first comprehensive plan for Amman's future extension was introduced by the municipality of Amman, where the separation of private from public space on the basis of ownership and land use took place. The Abdali district started to appear at that time where the western planning ideology of having divisions of urban space according to isolated functional criteria, with separate areas for housing, commerce, industry and other uses started to spread. The international style started to dominate the public buildings of Amman, with the importation of building materials from different parts of the world. The dwelling architecture remained intact during this phase. The Abdali district was first used for commercial space and offices. The total area of Amman reached 120 square kilometers with inhabitants of over 350 thousand. Between, 1967 and 1976, a huge number of refugees arrived in Amman due to the Arab-Israeli war of 1967. The total population reached over 550 thousand and the area of Amman increased to 160 square kilometers. This phase is distinguished by the spread of irregular layout planning, due to the large number of refugees in need of housing. A mixture of land use began to spread throughout the city, especially at Abdali, and privacy of residential houses began to be lost. Between 1976 and 1987 the total inhabitants reached 960 thousand, and the area of Amman reached 350 square kilometers. The city spread in nearly all directions, and especially over the western and northern sections of the city, where the cultivated land began to decrease gradually. In 1987 the Greater Municipality of Amman was established and the total area of Amman increased greatly. In 1989, the total number of inhabitants exceeded one million for the first time, and now it is more than 2.03 million. The total area of Amman reached 677 square kilometers in the year 2003. A sudden increase in the population also accompanied the Gulf War of 1991 due to Jordanian workers returning from Kuwait and Iraq. This put pressure on Amman's infrastructure and increased the value of lands, therefore putting much pressure on the middle and low income housing projects.

\subsection{Abdali Redevelopment Project}

The Abdali site was originally intended for army and military administration (Fig. 1). Its total area is about 330,000 square meters. In the year 2002 concern with economic performance dominated the urban agenda of Amman. Amman followed distinctive development trajectories that reflected both the interactions of global forces and local community. The primary global force of Amman is the competitive international environment engendered by economic globalization that moves the city towards an attractive location for investment. This competition is manifested in city marketing strategies that impact the desire to attract multinational corporations and specialists [2]. The political ideology of the city plays an important role in the globalization process, as Newman \& Thornely, 2005 explain, which is occurring now in Amman [3]. Amman's situation is a mixture between state control and economic liberalism in which urban development is determined by the planning vision of attracting foreign 
investment and reduce restrictions to free enterprise. Amman presents an example of global economic forces that occur in developed society. The Abdali redevelopment project is working to establish a good position within the global economy. The infrastructure was nearly $70 \%$ complete between 2003 and 2005 . The political stability of Jordan, the strong inward flows of capital investment especially from the harir company named Saudi Oger, and the cheap workers are all factors that lead the way towards good urban generation at Abdali.

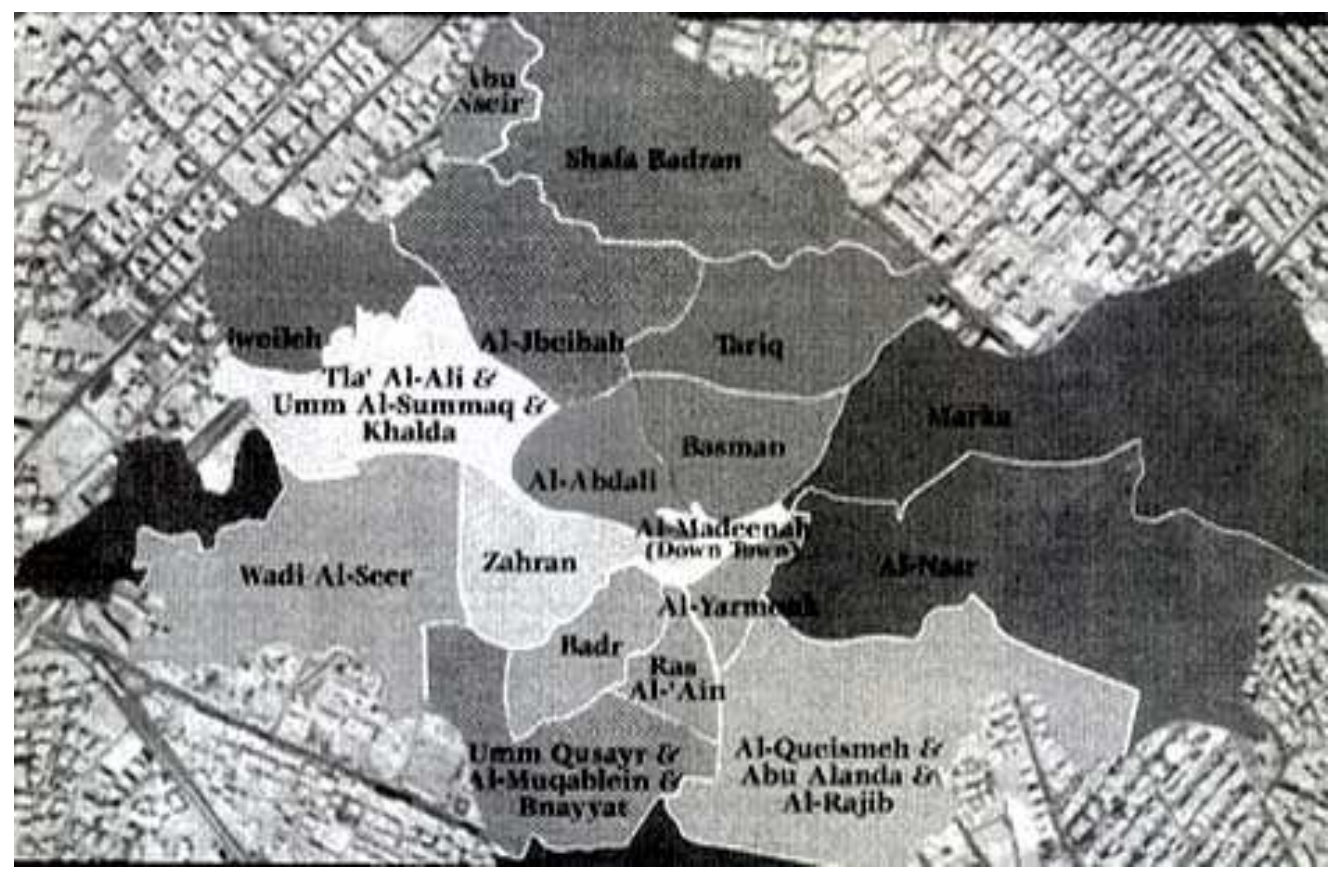

Fig. 1: Map of Amman showing Abdali in the heart of the city.

Source: National Resources Investment \& Development Corporation, 2005.

Approx. Scale: 1:5000 $2.5 \quad 5.0$ 7.5

The Abdali site contains primarily four projects: 1 . The office and retail buildings owned by Saudi Oger group, which exist at the western part of the project, with a total built area of nearly 320,000 square meters as seen in Fig. 2. It will host three high rise buildings, one of which will reach 220 meters in height, the highest in the skyline of Amman. Le Royal building completed in 2003, will no longer continue to be the highest point with 110 meters height. 2. The American University of Jordan for higher education campus will occupy the northern part of the site as in Fig. 3. Its total area is about 140,000 square meters. 3. The library of the late King Hussein of Jordan, which will occupy the eastern section of the site near the Parliament and Court of Justice buildings. Its total area is about 60,000 square meters. 4. The rest of the developed area of around 510,000 square meters will be sold to local and foreign investors as shops and offices. The site will incorporate a well-designed plaza to the western part of the site. It will be connected to the eastern section of the site by a pedestrian spine, like the old bazaar of traditional Middle Eastern cities. 


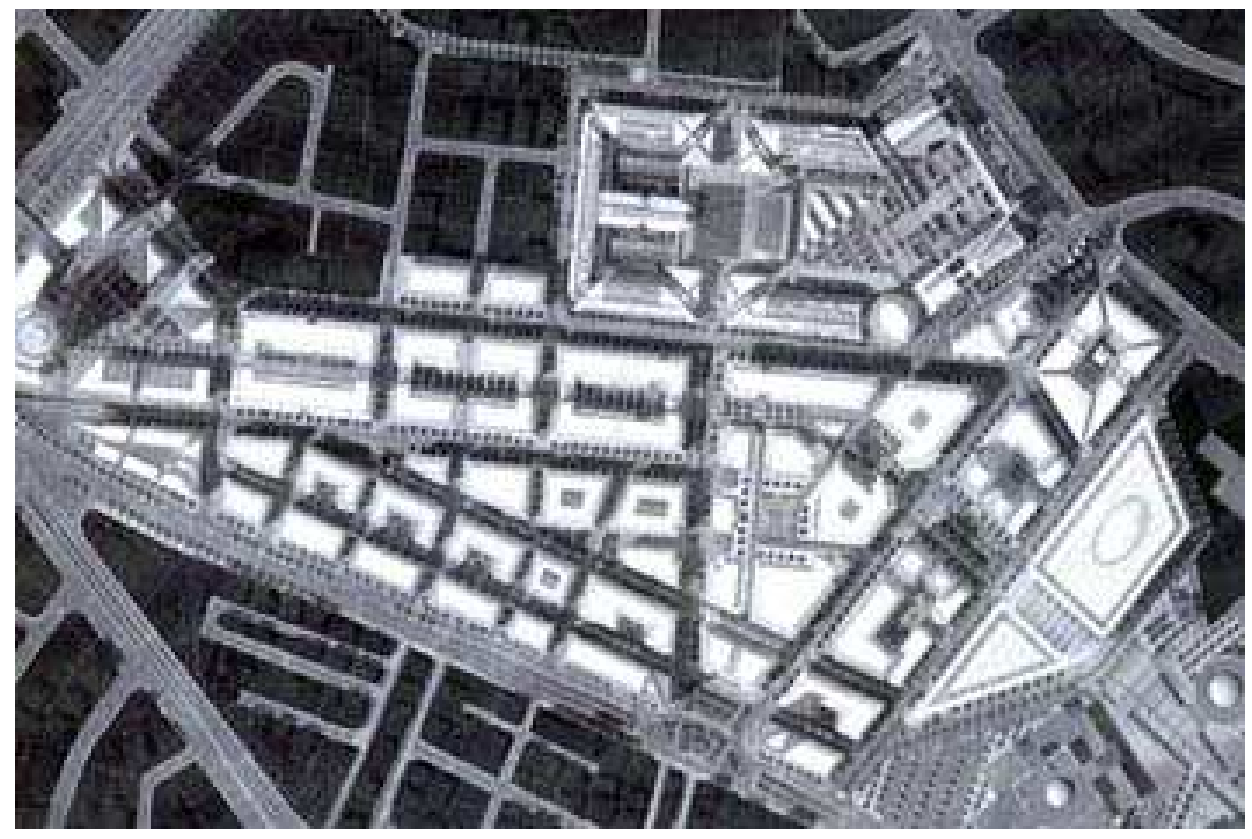

Fig. 2: Mater plan of the redevelopment of Abdali project.

Source: National Resources Investment \& Development Corporation, 2005. Approx. Scale: 1:500 0.25

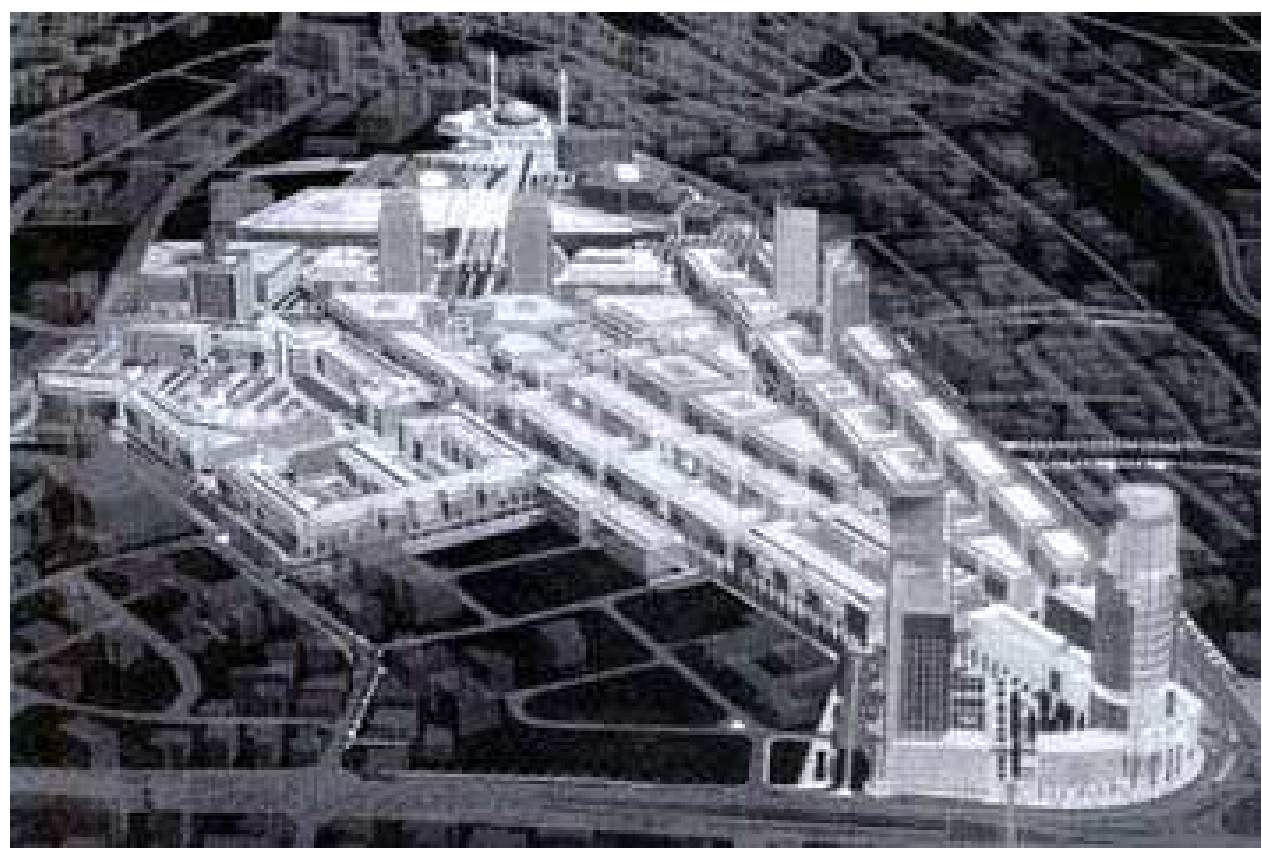

Fig. 3: Isometric image of the redevelopment of Abdali project. Source: National Resources Investment \& Development Corporation, 2005. 


\section{QUALITY OF LIFE}

\subsection{Quality Of Life Concept}

The quality of life concept is suggested not as a new indicator or alternative to social, economic or environmental studies, but as a more complex, multidirectional goal [4]. The quality of life concept encompasses many domains and sub-domains of life indicators in addition to many variables and values of the society and environment [5]. It is indeed a well-developed phase to all social, economic and environmental research that is primarily descriptive, secondly evaluative. It is concerned with personal well being and satisfaction and with living conditions of places [6]. Economists deal with quality of life as a matter of living conditions. It depends on the conveniences of people's daily lives and is measured by total consumption of goods and services as well as the quality of them [7]. While socialists see quality of life as a subjective instrument, economists see it as an objective instrument. Subjective quality of life is about feeling good and being satisfied, such as psychological and behavioral dimensions of social order, safety and communication, while objective quality of life is about fulfilling the societal demands in the surrounding environment, such as infrastructure and public service provision [8]. Both subjective and objective dimensions are included at the individual and society or community levels. At the individual level, subjective quality of life refers to life satisfaction and sense of well being and how people feel about themselves and their circumstances, while at the community level it is related to the ability to participate and influence decisions. Objective quality of life at the individual level implies a functional assessment and level of educational status, while at the community level it implies environmental, social, economic conditions, government performance, and population statistics of health and growth status [9].

The quality of life is a compound concept of life satisfaction and standard of living that must be studied parallel to each other. In other words, the standards of living may be improving, but the quality of life may not be so at the same level. People might also be satisfied with their circumstances of their living with an environment that is of poor quality, and not aware of better possibilities [10]. Quality of life and social, economic and environmental studies are being proactive. In order to move from indicators to action, projects must examine and analyze the causes behind the symptoms [11]. A quality of life program requires a clear conceptual base to be built upon and to analyze accordingly to become usefully effective. This base defines the problem under consideration and builds a clear understanding of what needs to be measured [12].

In order to measure a quality of life in any district or city, developed indicators must be tested first. The study area or size is crucially important to determine the data available and required. Some data might be required at the scale of the city, while others at the scale of the neighborhood. The time frame of collected data is also important. Some intervals are for ten years, some of five, some yearly and some sporadically [13]. The domains and the elements underneath indicators are joined together by means of a framework that describes the relation between all domains and indicators [14]. 


\subsection{Domains Selection Criteria}

Domains vary in scale, time frame and terminology. The following issues must be incorporated and taken into consideration as Hagerty et. al, 2001 suggested: 1. The domains must represent the total construct or at least as much components as possible. 2. Each domain must encompass a substantial and discrete portion. Thus, strongly related aspects could be joined together under one major domain. 3. Domains must be more generic to cover various kinds of population, such as elderly people and other kinds. 4. Domains must have the potential to be measured in both subjective and objective quality of life dimensions [15] Developing countries' quality of life domains differ from those of developed countries. The focus on the fundamentals in developing countries such as availability of jobs, shelter and security is stressed, while less importance is paid to amenities, recreational opportunities, a satisfying personal and professional life and a pleasant community [16]. Each country can determine its properties. Developing countries lack research about local quality of life, domains and indicators studies.

\section{CONCEPTUAL FRAMEWORK AND DATA COLLECTION CRITERIA}

There are different methods to measure quality of life, and there is no single correct method to obtain quality of life data. Interviewing is the most suitable means of data collection. It can be achieved face to face, by internet or by telephone. It can be individual or group interviewing. Individual interviewing is based on asking each respondent alone a series of pre-established questions, where the main idea is gathering data from separate individuals without others' influences [17]. Group interviewing is a systematic questioning of several individuals simultaneously, where the researcher brings together several people to try out a definition or a methodological technique to his problem [18]. Three well-known and established techniques that are in quality of life studies are:

3.1 Concept Mapping Technique, which focuses on a topic involving input from one or more participants that produces a diagram of their perceptions. It helps people thinking more effectively as a group without losing their individuality. There is no strict number of people participating [19]. In this study, 25 experts from various fields are joined together to give their views on the major domains that affect Abdali district, where table 1 is the result. Experts are selected through email and internet and the choice to participate depends on the degree of their responses and applicability of reaching the respondents. Different domains are suggested and discussed, and finally, nine domains are chosen that cover nearly all aspects of Jordanian life at Abdali district. Concept mapping is led by the author of this paper and in the end, all 25 participants were thanked for his or her time and participation.

3.2 Focus Groups Technique, which requires the attendance of all participants in one place. It consists of qualitative interviews of from 6 to 12 people. Participants usually share their points and ideas together [20]. This method was not used in this research. 
Table 1: 25 expert's opinion on raking the Abdali domains out of ten, where the highest value means the most important domain.

\begin{tabular}{|c|c|c|c|c|c|c|c|c|c|}
\hline \multirow[b]{2}{*}{ No. } & \multicolumn{9}{|c|}{ Domain's value } \\
\hline & $\begin{array}{l}\text { Econ- } \\
\text { omy }\end{array}$ & Social & $\begin{array}{c}\text { Envir- } \\
\text { onment }\end{array}$ & \begin{tabular}{|c|} 
City \\
profile
\end{tabular} & Housing & Transport & $\begin{array}{c}\text { Recrea } \\
\text {-tion }\end{array}$ & $\begin{array}{c}\text { Public } \\
\text { participant }\end{array}$ & Legislation \\
\hline 1. & 9 & 7 & 8 & 6 & 5 & 4 & 2 & 3 & 1 \\
\hline 2. & 8 & 6 & 7 & 9 & 5 & 4 & 1 & 3 & 2 \\
\hline 3. & 8 & 6 & 9 & 7 & 5 & 4 & 3 & 2 & 1 \\
\hline 4. & 9 & 5 & 8 & 6 & 7 & 3 & 4 & 2 & 1 \\
\hline 5. & 7 & 5 & 8 & 9 & 6 & 3 & 2 & 4 & 1 \\
\hline 6. & 7 & 6 & 8 & 5 & 9 & 4 & 2 & 1 & 3 \\
\hline 7. & 8 & 6 & 7 & 5 & 9 & 4 & 1 & 3 & 2 \\
\hline 8. & 9 & 5 & 7 & 6 & 8 & 4 & 1 & 3 & 2 \\
\hline 9. & 6 & 5 & 8 & 9 & 7 & 3 & 1 & 4 & 2 \\
\hline 10. & 8 & 5 & 7 & 6 & 9 & 3 & 2 & 4 & 1 \\
\hline 11. & 8 & 6 & 7 & 5 & 9 & 4 & 2 & 3 & 1 \\
\hline 12. & 7 & 8 & 9 & 6 & 5 & 4 & 3 & 2 & 1 \\
\hline 13. & 9 & 7 & 8 & 6 & 5 & 4 & 2 & 3 & 1 \\
\hline 14. & 9 & 6 & 8 & 7 & 5 & 3 & 4 & 2 & 1 \\
\hline 15. & 8 & 6 & 9 & 7 & 5 & 3 & 2 & 4 & 1 \\
\hline 16. & 7 & 6 & 8 & 5 & 9 & 2 & 1 & 3 & 4 \\
\hline 17. & 7 & 5 & 9 & 6 & 8 & 4 & 3 & 1 & 2 \\
\hline 18. & 8 & 7 & 9 & 6 & 5 & 4 & 3 & 2 & 1 \\
\hline 19. & 8 & 5 & 6 & 7 & 9 & 3 & 4 & 2 & 1 \\
\hline 20. & 9 & 5 & 7 & 6 & 8 & 3 & 4 & 2 & 1 \\
\hline 21. & 9 & 6 & 8 & 7 & 5 & 4 & 3 & 2 & 1 \\
\hline 22. & 8 & 5 & 7 & 6 & 9 & 2 & 3 & 4 & 1 \\
\hline 23. & 8 & 6 & 7 & 5 & 9 & 4 & 1 & 2 & 3 \\
\hline 24. & 7 & 6 & 8 & 5 & 9 & 4 & 3 & 2 & 1 \\
\hline 25. & 7 & 6 & 8 & 5 & 9 & 3 & 4 & 1 & 2 \\
\hline Sum & 198 & 146 & 195 & 157 & 179 & 87 & 61 & 64 & 38 \\
\hline
\end{tabular}

3.3 Delphi Technique, which uses a focused questionnaire approach in order to establish a consensus opinion from people that do not necessary know each other and can be made through email or internet [21]. This study made use of the Delphi technique, where 200 inhabitants living around Abdali project participated in filling out the questionnaire, which is presented in table 3.

This study tried to look for the domains that are of the highest influence on quality of life to residents of Amman in general, and to the residents of Abdali in specific. It classified them into ranks according to their importance as shown in table 2. In order to ensure accuracy table $\mathbf{4}$ is suggested for analysis, which analyzes table $\mathbf{1}$ according to frequency of values. Finally a Box and Whisker Plot to all nine domains is drawn, as in table 5. It points out the extreme values and their relationship to each other. 
Table 2: Statistical values of the main domains shown in table 1.

\begin{tabular}{|l|c|c|c|c|c|c|c|}
\hline \multicolumn{1}{|c|}{ Domain } & $\begin{array}{c}\text { Total value } \\
\text { gained }\end{array}$ & $\begin{array}{c}\text { Highest } \\
\text { value }\end{array}$ & $\begin{array}{c}\text { Lowest } \\
\text { value }\end{array}$ & Rank & Mean & Variance & Median \\
\hline Economy & 198 & 9 & 6 & 1 & 7.92 & 0.72 & 8 \\
\hline Social & 146 & 8 & 5 & 5 & 5.84 & 0.56 & 6 \\
\hline Environment & 195 & 9 & 6 & 2 & 7.8 & 0.51 & 8 \\
\hline City profile & 157 & 9 & 5 & 4 & 6.28 & 1.26 & 6 \\
\hline Housing & 179 & 9 & 5 & 3 & 7.16 & 3.81 & 7 \\
\hline Transport & 87 & 4 & 2 & 6 & 3.48 & 0.42 & 3 \\
\hline Recreation & 61 & 4 & 1 & 8 & 2.44 & 1.16 & 2 \\
\hline $\begin{array}{l}\text { Public } \\
\text { Participant }\end{array}$ & 64 & 4 & 1 & 7 & 2.56 & 0.99 & 2 \\
\hline Legislation & 38 & 4 & 1 & 9 & 1.52 & 0.4 & 2 \\
\hline
\end{tabular}

Table 3: Questionnaire on Abdali redevelopment project according to their ranks as in table 2 where total for each cell is 200 participant. Source: Author, 2005.

\begin{tabular}{|c|l|c|c|}
\hline No. & \multicolumn{1}{|c|}{ Question } & Yes & No \\
\hline 1. & $\begin{array}{l}\text { Do you think that Abdali redevelopment project will improve } \\
\text { economical situation at Amman? }\end{array}$ & 178 & 22 \\
\hline 2. & $\begin{array}{l}\text { Do you think that Abdali redevelopment project will improve } \\
\text { the whole environment in the district? }\end{array}$ & 164 & 36 \\
\hline 3. & $\begin{array}{l}\text { Do you think that Abdali redevelopment project will provide } \\
\text { for better housing environment? }\end{array}$ & 148 & 52 \\
\hline 4. & $\begin{array}{l}\text { Do you think that Abdali redevelopment project will introduce } \\
\text { a new and desirable city profile and skyline? }\end{array}$ & 156 & 44 \\
\hline 5. & $\begin{array}{l}\text { Do you think that Abdali redevelopment project will facilitate } \\
\text { for social interaction? }\end{array}$ & 154 & 46 \\
\hline 6. & $\begin{array}{l}\text { Do you think that Abdali redevelopment project will improve } \\
\text { transportation system in the area? }\end{array}$ & 108 & 92 \\
\hline 7. & $\begin{array}{l}\text { Do you think that Abdali redevelopment project took the } \\
\text { public opinion in its design? }\end{array}$ & 22 & 178 \\
\hline 8. & $\begin{array}{l}\text { Do you think that Abdali redevelopment project will provide } \\
\text { for recreation area? }\end{array}$ & 188 & 12 \\
\hline 9. & $\begin{array}{l}\text { Do you think that Abdali redevelopment project will lead for } \\
\text { better building legislation? }\end{array}$ & 122 & 78 \\
\hline
\end{tabular}

\section{DISCUSSION OF THE MAIN DOMAINS OF ABDALI REDEVELOPMENT STUDY}

As discussed in the conceptual framework and data collection, a concept mapping technique is used to interview 25 experts. There were several domains prepared for discussion by the author, and after discussion with the selected experts, nine domains were chosen. They will be discussed in detail as follows: 
Table 4: Domain's frequency of values based on table 1 analyses.

\begin{tabular}{|l|c|c|c|c|c|c|c|c|c|c|}
\hline \multicolumn{1}{|c|}{ Domain } & \multicolumn{9}{|c|}{ Frequency of values } \\
\cline { 2 - 13 } & $\mathbf{1}$ & $\mathbf{2}$ & $\mathbf{3}$ & $\mathbf{4}$ & $\mathbf{5}$ & $\mathbf{6}$ & $\mathbf{7}$ & $\mathbf{8}$ & $\mathbf{9}$ & Total \\
\hline Economy & - & - & - & - & - & 1 & 8 & 10 & 6 & 25 \\
\hline Social & - & - & - & - & 9 & 12 & 3 & 1 & - & 25 \\
\hline Environment & - & - & - & - & - & 1 & 8 & 11 & 5 & 25 \\
\hline City profile & - & - & - & - & 7 & 10 & 5 & - & 3 & 25 \\
\hline Housing & - & - & - & - & 9 & 1 & 2 & 3 & 10 & 25 \\
\hline Transport & - & 2 & 9 & 14 & - & - & - & - & - & 25 \\
\hline Recreation & 6 & 7 & 7 & 5 & - & - & - & - & - & 25 \\
\hline Public participant & 3 & 10 & 7 & 5 & - & - & - & - & - & 25 \\
\hline Legislation & 6 & 6 & 2 & 1 & - & - & - & - & - & 25 \\
\hline
\end{tabular}

Table 5: Box \& Whisker domains of table $2 \& 4$, out of ten, where the highest value means the most important domain.

\begin{tabular}{|c|c|c|c|c|c|c|c|c|c|}
\hline 9 & & & & & & & & & \\
\hline
\end{tabular}


4.1 Economy Domain: In developing countries, economic indicators are considered a very important issue that influences almost every individual. In general, if a city has a good economic performance it will have a high standard of living [22]. The figures for total Gross National Product, GNP, are US\$ 6.6 billion in Jordan. The yearly individual income is averages approximately US $\$ 1,200$, far less than other surrounding countries. The unemployment figure is $9.1 \%$ for Amman City [23]. The poverty line is calculated to be around US\$ 500 per year per person. In Amman City 9.2\% of the population is below the poverty line, less than the figure for Jordan, which is $14.2 \%$. The foreign investment is around US\$ 140 million in the year 2004, about one fourth the total investments for the same year. Amman City has the greatest amount of investments, about $72.6 \%$ of the total amount [24].

4.2 Social Domain: Social situation of the community is highly related to the economy. The social satisfaction of inhabitants is relative to figures of rate of savings of private households and their satisfaction with their income. The average working hours per week is associated with people's productivity that classifies them into low, medium, and high income groups. The total number of population in Amman is $2,027,685$, about $38.1 \%$ of the Jordan's population, of which $1,061,890$ or $52.4 \%$ are males. The newborn percentage is $2.6 \%$ and the death rate is $0.32 \%$. Almost $91.4 \%$ of Amman's inhabitants are urbanized and only $8.6 \%$ living in rural areas [25]. Health is considered part of the social satisfaction of the society. As the level of health increases the potential of happiness does too; thus good health results in a better quality of life. Good health leads to higher income due to better productivity and larger labor force participation [26]. In Amman the health situation is generally good. The lack of awareness of people of poor eating habits and unhealthy lifestyles has led to the spread of diabetes and cardiovascular diseases. Air pollution, noise and stress are all factors that strongly contribute to the spread of diseases. The health service in Amman is sufficient in terms of the number of physicians, but not so in nurses. Medical insurance does not cover the whole society. For those without coverage the treatment is costly.

4.3 Environment Domain: Until recent times, environment was not considered an important aspect when studying people's living conditions although it has a great influence on people's quality of life. Environment is related to all our surroundings, including built and natural environments [27]. Natural environmental quality includes air, water, soil and natural resources, while built environment is related to other fields such as infrastructure, energy, employment, transportation, recreation, housing and public safety. Natural environmental factors are in direct relation to population growth, wastes and emissions, energy consumption, and pollution [28]. The existing situation in Amman and around Abdali has a lot of traffic congestion and growth of business and activities that leads to an unpleasant environmental situation. The air pollution due to traffic congestion is one major problem at Abdali district that affects people's quality of life. Solid waste treatment is also inefficient at Abdali. Recycling is not yet employed. This might improve the environment and provide a better quality of life satisfaction. The lack of open spaces and green area at Abdali district increases the air and noise pollution. At Abdali redevelopment project this problem might be partially solved as the provision for open spaces and plantation is anticipated in the design scheme. 
4.4 City Profile Domain: The growth of Amman is happening at incredible rates, as described before. Capital cities usually encourage most people to live or at least work inside them for better services and daily life facilities, thus increasing nonhomogeneous population that makes integration between community members difficult. This results in an increased number of crimes in the society and raises the question of solidarity among the community's families. The urban fabric of the city reflects the social interaction of its people, that is reflected in the city skyline, which is considered an important element in the quality of life [29]. The Abdali redevelopment project will provide a completely new skyline to the district of Abdali and to the whole city of Amman, where high rise buildings will be the dominant feature. The design suggests building several high rise buildings ranging from 12 to 50 meters high. The current legislation situation at Amman allows for only 12 meters in residential districts and up to 30 meters in commercial zones with other rules and restrictions that are applied. Figures 1 and 2 show the difference in urban fabric between existing and proposed designs.

4.5 Housing Domain: Housing is considered an important element in quality of life. It is not a shelter alone. It has physical and socioeconomic prospects. Poor quality of housing causes diseases and affects health. Providing for adequate housing schemes is an indicator of good social policy in the country. The provision for housing should anticipate people's requirements in terms of type, size, style of finish and utilities [30]. Building regulations greatly affect the type and form of the housing schemes. The costs and property taxes affect rental prices that influence quality of life. The more the inhabitants pay in taxes, the smaller the resulting house. The services related to housing are also important such as the provision of car parking, which is one of the most serious problems in Abdali. The need for car parking in this district is an urgent matter that should be resolved before completing the Abdali redevelopment project.

4.6 Transport Domain: It is related to the problems of traffic congestion, noise and pollution. It plays a significant role in quality of life. It is a service that everyone needs [31]. The convenience of travel within Amman City by public means of transport is bad. There is no underground or "metro" means of transportation, and the existing public buses are not sufficient and are mostly inconvenient. In Abdali district the situation is much worse because of the high density of the district near the downtown. The time needed to travel within the Abdali district is increasing and the cost is rising. The redevelopment project will make the problem even worse due to the large development and investment area. It will increase density in the area without providing for public transportation. Although a large boulevard will be constructed at the lower edge of the redevelopment site that will facilitate private cars' movement, still the public transportation problem is not solved. The Privatization process now taking place at Jordan might be the answer to some existing infrastructure problems. Much of the traffic congestion is now resolved by the construction of bridges, tunnels and by-pass roads that ease vehicle movement but without parallel treatments to pedestrian and pavement walks. At Abdali redevelopment project a complete pedestrian arcade of more than 500 meters long will be designed through the buildings layout to solve the above mentioned problem. There are about 500 public buses in Amman, but carry only $16 \%$ of total passengers, while about 12,000 taxis and white cabs (called service) for 
$20 \%$ of total passengers. The remaining $64 \%$ use private cars that account for more than 500,000 vehicles in Amman alone [32].

4.7 Recreation Domain: Recreation is a vital issue in people's lives. It is the main theme that distinguishes human beings from other creatures [33]. The daily human needs require a certain level of open space and green area such as public parks [34]. Amman's urban tissue suffers from a lack of recreational facilities, and even if they exist, they are not activated or suffer from poor maintenance. Indoor leisure activities do exist but only in a few locations. Public parks in Amman suffer from inadequate facilities. Their distribution is spontaneous and they usually suffer from poor design and furnishings such as fountains, chairs on which to rest, kiosks, cafes and other leisure facilities. Sports activities are very limited. They exist only in private clubs in which cost is prohibitive for low and middle income people. The children also suffer from a lack of recreation opportunities. The zoning plan for Amman recently started to provide for recreational facilities in some districts. The Abdali redevelopment project provides a small area as an open plaza, which is located at the western edge of the project, as seen in figure 1. It contains a fountain, but no other recreational facilities are provided or designed.

4.8 Public Participant Domain: It is an important new domain in the Middle East that started to take place in developing countries recently. Public participation requires a certain degree of education and awareness of the society's needs and requirements. People as a result of their participation feel that they are part of the community they live in. In order to be effective citizens, people should participate in community and city decisions [35]. Although there are many charity associations and international organizations in Amman, people participation is limited for various reasons. One reason might be the non-homogeneous population of the city of Amman and the various concerns about personal interests. The Municipality of Amman has not made any effort to bring public participation into reality. It has not asked its inhabitants their opinions on any suggested project. Even the new Abdali redevelopment project does not take into consideration many of the people's needs and requirements. Most residents of Amman in general and at Abdali district specifically, do not know the basic components of the project. They are only aware that there will be a huge redevelopment to the old site of the army headquarter without even knowing the functions or zones of the project. All designs are not easily accessible. Citizens do not know what the design and style of the buildings will be, and the legislation and regulations inside this project are unknown. They only know that the municipality of Amman general legislation will not be applied inside this project. Public participation is clearly missing in this project as well as other projects of Amman.

4.9 Legislation Domain: The first law for building regulations in Jordanian cities was introduced in 1955. A year later the first comprehensive plan for Amman's future extension was introduced by the municipality of Amman. The first law for building regulations for Amman was introduced in 1965, incorporating the western planning ideology of having divisions of urban space according to isolated functional criteria, with separate areas for housing, commerce, industry and other uses. In 1977 a committee was created to lay down a metropolitan comprehensive plan for Amman, 
followed by the second law for building regulations for Amman in 1979. This law was revised in 1984 and again in 1993. In 1987 the Greater Municipality of Amman was established and the total area of Amman increased greatly. In 1988 the national comprehensive plan for Greater Amman was developed. This phase was marked by the advent of erecting high rise buildings in the Amman area that exceeded one hundred meters in height. In 2005 a revision to the law of 1979 occurred especially addressing construction of high rise buildings [36]. The public does not yet know the exact legislation for Abdali redevelopment project-that it will allow for higher buildings in the city skyline rather than other districts in Amman.

\section{RESULTS}

This study started with the Concept mapping technique to select different domains that affect the Abdali district quality of life. This approach is more a qualitative than quantitative approach. Next a Delphi technique was applied for the purpose of studying the expected future influence of the Abdali redevelopment project on people's quality of life. This does not mean reduction of the importance of the Focus Groups technique as a useful tool for quality of life researchers. The 200-participant sample is considered a good number in terms of quality of life questionnaires. The bigger the sample is, the more accurate the results that can be obtained. The evident result obtained from table 1 is the wide variation that appeared in participants' opinions and level of priorities of the first five domains, which are economy, social, environment, city profile and housing if compared to the other four domains. The other four domains of transport, recreation, public participation and legislation are considered as partial domains by all 25 of the selected experts who participated in the study. Table 2 summarizes these results, ranking them and showing the average for each domain. Economy is the most important domain followed by environment, housing, city profile and social domain respectively. On the other hand, ranking legislation, recreation, public participation and transport are at the other end, expressing an ordinary situation in a developing country, as table 5, Box and Whisker Plot shows. Only the transportation domain is strange to be the $6^{\text {th }}$ in rank. It also should be stressed that these domains are applicable and valid for Abdali district only and might be so for Amman, but definitely will change if applied to other cities in Jordan or in the Middle East.

The Abdali redevelopment project will not change many of the aspects of life of inhabitants at Abdali alone, but it will affect the whole city of Amman and alter its skyline. Table 3 demonstrates the positive perspective of the participants in nearly all domains except that of question 7 , which is about public participation in the design and layout of the project. In the economy domain the participants think that the project will improve the economy and social life of people. Almost 89\% of those who answered question number 1 are in favor of the improvement of economic situation due to the large amounts of developed area. The construction of over one million square meters will require skilled laborers during building. After construction, the project will stimulate growth in retail sales, business and commerce. The establishment of the American University at Jordan will stimulate growth in education. The social domain is related to economy as indicated previously. Almost $77 \%$ of participants see that the new project in Abdali will improve the social life of the community. Social life is 
related in a way to health, which is not one of the major domains discussed before. Health service at Amman is sufficient for those who have medical insurance, but for those without coverage the treatment is costly and likely inconvenient.

For the environment domain, $82 \%$ of participants think that the Abdali redevelopment project will improve the local environment. The infrastructure laid down is new and advanced in terms of technology and technique; thus, it will improve the spatial quality of local environment, and hopefully, it will reduce pollution. The provision of new open space with fountains, a bazaar, an arcade is considered a positive element in people's opinions. In the city profile domain, $78 \%$ of participants in question number 4 see that the new redevelopment project will provide for a new and desirable concept in urban design. The new high rise buildings will introduce a completely new skyline for the district of Abdali and Amman as a whole. As Evenson, 1981 commented, many inhabitants and even architects and planners are coming to believe that high rise buildings is the normal building form for a modern city and the symbol of modern architecture [37].

Although it is not yet clear the exact area of the residential section at the Abdali redevelopment project (about 132,000 square meters) almost $74 \%$ of the sample in question number 3 , table 3 , see that this project will ensure a better housing environment. It is not certain that people's requirements are taken into account when designing this project. Inhabitants usually like to live in individual types of houses (called villas) of areas around 200 square meters, which is not the case in this project at all. The housing schemes, if they exist, will be high rise apartment style. People of Jordan, as statistics show, do not prefer this kind of housing. The problem of car parking will be another important issue to discuss in this redevelopment project. The area for development is limited and the provision for car parking will be a problem if large-scale housing projects are implemented.

Although the transportation domain rank is $6^{\text {th }}$ in table 1 , it is considered an important issue to every citizen living in the city. The construction of a large boulevard at the lower edge of the redevelopment site will facilitate vehicle movement, yet the public transportation problem is not solved. The public transportation problem should be addressed on a national level and the start of an underground transit project should accompany this redevelopment project. Nearly $54 \%$ of participants see that the Abdali redevelopment project will improve the transportation system in the area, but I think they are too optimistic. Recreation provision in the new development of Abdali is limited, but people see the small plaza and shopping arcade and bazaar as a core for such a facility. $94 \%$ of participants support this idea, due to their ignorance of other recreational facilities existing in other cities. As mentioned before, recreational facilities are very limited in Amman City, and even if they exist, they are of poor situation and condition due to neglect in maintenance.

Question number 7 shows the very low percentage (only $11 \%$ of participants) of public opinion consideration. The municipality did not tackle this issue in the Abdali redevelopment project nor in any other project. As discussed before in this study this situation should not continue. People's participation will provide for better 
environmental qualities, thus it will influence the whole life of the citizens. Legislation domain is related in a way to public participant domain. There was a discussion by experts held by Municipality of Amman before introducing the new amendments of law in Amman in 2005, but it was minor and ineffective. Most of the remarks given to the municipality in a seminar were not taken into consideration, especially for the part of high rise building location. $61 \%$ of the participants of the question number 9 , table 3 see that this new project will lead to improvements in legislation. In the end, as concluded by this study, the redevelopment project of Abdali might improve the quality of life but only to a certain level as discussed before. Future studies will determine the exact situation, but some of the above mentioned recommendations should be incorporated in the design process before completing the project.

\section{ACKNOWLEDGEMENTS}

I would like to thank Mr. Robert La Rock, an American English language teacher living in Jordan for his help in editing this paper.

\section{REFERENCES}

[1] Municipality of Amman, (2002), Amman history and civilization, Municipality of Amman Press, Amman.

[2] Taylor, P., (2001) World Cities and territorial states under conditions of contemporary globalization, Political Geography, Vol . 19

[3] Newman, P., Thornely, A., (2005), Planning World Cities: Globalization and politics, Pelgrave Macmillan, Basingstoke .

[4] Land, K., (2002) Social indicators and quality of life, In: Edgar, F., Borgotta \& Marie L., (Eds) A revision to the entry, Encyclopedia of sociology.

[5] Flynn, P., Berry, D., Heintz, T., (2002) Sustainability and quality of life indicators: Towards the integration of economic, social and environmental measures, The Journal of Social Health, Vol. 1 No. 4.

[6] Jones, A., Riseborough, M., (2002) A guide to doing quality of life research, Center of Urban \& Regional Studies, University of Birmingham, U.K

[7] Lu, J., Peng, A., Xing, S., (2001) The quality of urban life in Mainland China, Conference of the Asian Consumer and Family Economics Association, and the China Consumer Economics Research Association, China,

[8] Lugger, M., (1996) Quality of life differences and urban and regional outcomes: A review. Housing Policy Debate, Fannie Mac Foundation, Vol. 7, No. 4 P. 749771

[9] Hancock, T., (2000) Quality of life indicators and the DHC. Health Promotion Consultant, Kleinburg, Ontario .

[10] Yeih, K., Chiao, Y., Yu, S., (2001) Life satisfaction in Taiwan, Conference of the Asian Consumer and Family Economics Association, and the China Consumer Economics Research Association, China .

[11] Cobb, C. W., Rixford, C., (1998) Lessons learned from the history of social indicators, Redefining Progress, San Francisco.

[12] Ferriss, A. L., (2001) Measuring the domains of quality of life, Department of Sociology, Emory University, Atlanta, 
[13] Hagerty, M., Cummins, R., Ferriss, A., Land, K., Michalos, A., Peterson, M., Sharpe, A., Sirgy, J., Vogal, J., (2001) Quality of life indexes for national policy: Review and agenda for research, Report to the Committee for Social Quality of life Indexes, IS QOLS.

[14] Jones, A., Riseborough, M., (2002) Comparing quality of life researchInternational lessons. Center of Urban \& Regional Studies, University of Birmingham, U.K.

[15] Hagerty, M., Land, K., (2002) Constructing summary indices of social well being: A model for the effect of heterogeneous importance weights. Annual meeting of the American Sociological Association, Chicago.

[16] Andrews, C. J., (2001) Analyzing quality of place, Environment \& Planning B: Planning \& Design, Vol. 28, P. 201-217.

[17] Marans, R., (2002) Measuring quality of life using subjective and objective indicators: The metro Detroit experience, ACSP, Baltimore.

[18] Denzin, N., Lincoln, Y., (1994) Handbook of qualitative research, SAGE Publications, U.S.A

[19] Trochim, W., (1993), The reliability of concept mapping, Annual Conference of the American Evaluation Association, Dallas.

[20] ASA Series, (1997), What are focus groups? American Statistical Association, Alexandria, U.S.A

[21] Nicholas, A., Zumbo, B., (1997), Public services and quality of life, University of Northern British Colombia.

[22] Bloom, D., Craig, P., Malaney, P., (2001), The quality of life in rural Asia, Oxford University Press, Hong Kong.

[23] Statistical Department of Jordan, (2005), Annual Report of 2004, Statical Department of Jordan Press, Amman.

[24] Ministry of Commerce and Industry, (2005), Annual Report of 2004, Ministry of Commerce and Industry Press, Amman .

[25] Statistical Department of Jordan, op.cit .

[26] Banerjee, T., Southworth, M., (1991), City Sense and city design: Writings and projects of Kevin Lynch, MIT press, Cambridge .

[27] Rahman, T., Mittelhammer, R., Wandschneider, P., (2002), Measuring the quality of life across countries: A sensitivity analysis of well being indices. WIDER International conference on Inequality, poverty and human well being, Helsinki.

[28] Smeets, E., Weterings, R., (1999) Environmental indicators: Typology and preview, European Environment Agency, Copenhagen.

[29] Friedmann, J., (2002), The prospects of cities, University of Minnesota Press, Minneapolis.

[30] Fried, L., (1990), Makers of the city, University of Massachusetts Press, Cambridge.

[31] Bartuska, T., Young, G., (1994), The built environment: Creative inquiry into design and planning. Crisp Publication, California .

[32] Ministry of Interior, (2005), Annual report of 2004, Ministry of Interior Press, Amman .

[33] Stein, J., (1995), Classic readings in urban planning: An introduction, McGraw Hill, New York. 
[34] Broadbent, G., (1990), Emerging concepts in urban space design, Van Nostrand Reinhold, London.

[35] Douglass, M., Freidmann, J., (1998), Cities for citizens: Planning and the rise of civil society in a global age, John Wiley, New York.

[36] Municipality of Amman, (2005), Annual report of 2005, Municipality of Amman Press, Amman.

[37] Evenson, N., (1981), The city as an artifact; building control in modern Paris, In: Kain, R. (Ed), Planning for Conservation, Mansell, London.

\section{هل تطوير منطقة العبلدي ستحسن من مستوى المعيشة

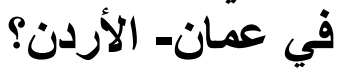

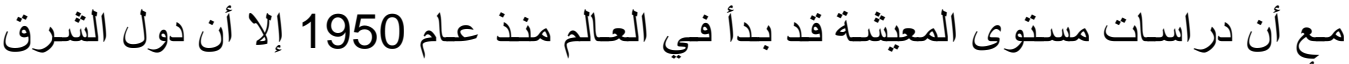

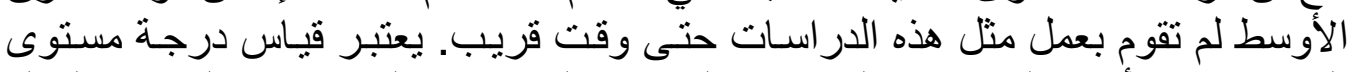

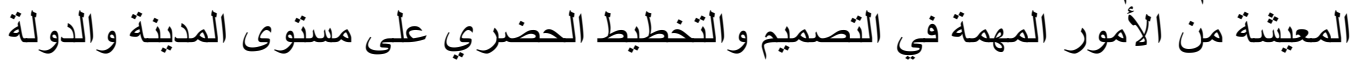

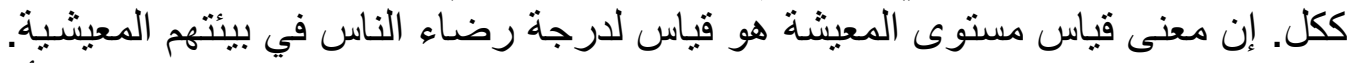

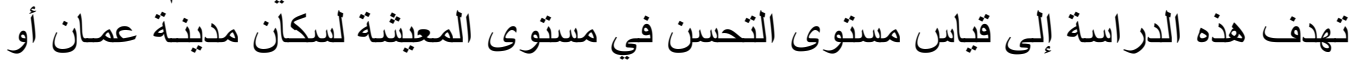

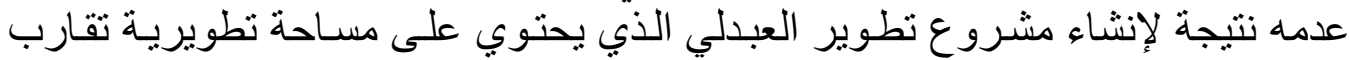
350000 منر مربع وتكلفة تزيد عن بليون دولاءر أمريكي والذي الذي بدأ العدل بـه أو ائل عام 2006. 